\title{
İki teori, iki pratik ya da olağanüstü olağana karşı
}

\section{Ertan ENGÍN1}

\begin{abstract}
APA: Engin, E. (2020). İki teori, iki pratik ya da olağanüstü olağana karşı. RumeliDE Dil ve Edebiyat Araştırmaları Dergisi, (18), 115-123. DOI: 10.29000/rumelide.705537.
\end{abstract}

\section{$\ddot{\mathbf{O} z}$}

\begin{abstract}
Ahmet Mithat ve Halit Ziya'nın roman anlayışları, deyiş yerindeyse, taban tabana zıttır. Vak'anın gelişimindeki hız, tasvirlerde birkaç çizgiyle/fırça darbesiyle ve dolayısıyla bir eskizle yetinmek, (tutarlı ve kanlı-canlı bir)karakter yaratma kaygısından uzaklık, okuyucuyu etkilemeye/manipüleye meyyal anlatım/anlatıcı ve bununla ilintili olarak, karakterlerin anlatıda ahlak terazisinde ölçülüp tartılması.. Bu ve benzer unsurlar Ahmet Mithat kurmacasının belirgin nitelikleriyken, onun neredeyse üzerinde hiç durmadığı bir noktada derinleşmek de Halit Ziya romancılığının karakteristik, ayırt edici vasfıdır. Bahis konusu vasıf, duyguların tahlilidir. Ahmet Mithat romancılığında önemli olaylar dış dünyada gerçekleşirken, Halit Ziya romancılığında iç dünyada yaşanır. Roman türünü daha baştan; muhayyel/gerçek dışı/olağan üstü olana kökensel bağlılı̆̆ıyla tanımlayan ve bu tanımı bir postulat olarak kabul A. Mithat için zirvedeki romancı, Monte Kristo Kontu'nun yazarı Alexandre Dumas'dır. Halit Ziya ise, realist ve natüralist ekolün öne çıkan isimleri; Balzac, Flaubert ve Goncourt Kardeşler'e ilgisini yönelterek, romana dair tespitlerine onlardan delil getirir. O, romanda idealizmin ve eylemleri idealizm tarafindan yönlendirilen, anlamlandırılan tiplerin karşısındadır. Hatta böyle tiplerden, alay ve hor görüyle bahseder. Bu iki yazarın roman anlayışlarına dair önemli ipuçları Ahbar-ı Asara Tamim-i Enzar ve Hikâye adlı kitaplarında yer alır. Bu yazıda öncelikle söz konusu iki kitapta 'roman'a ve 'romancılık'a dair ipuçları üzerinde durulacak, sonrasında Henüz On Yedi Yaşında ve Sefile romanlarından hareketle iki yazarın romancılıklarına daha yakından bakılacaktır.
\end{abstract}

Anahtar kelimeler: Ahmet Mithat, Halit Ziya, Henüz On Yedi Yaşında, Sefile, roman.

\section{Two theories, two practices or the extraordinary against the ordinary}

\begin{abstract}
Ahmet Mithat and Halit Ziya have diametrically opposite perspective on novel, as the phrase goes. The swiftness of the course of events, contenting themselves with only few flicks/ brushstrokes and consequently with the only one draft, far from the concern of creating a (consistent and real) character, narration inclined to impressing/manipulating the reader, the narrator and affiliated to this, pondering the characters in the moral scale in the narrative. Whereas these sorts of similar elements are the distinctive features of Ahmet Mithat fiction, deepening at a point what Ahmet Mithat almost never deliberates is the characteristics and distinctiveness of Halit Ziya's novelism. The characteristic in question is the analysis of emotions. Important events take place in the outside world in Ahmet Mithat's novels, while they happen in the inner world in Halit Ziya's. For Ahmet Mithat who describes his novel genre originally adherence to the imaginary/unrealistic/dreamy one and who acknowledges this description as a postulate, the uppermost novelist is Alexander Dumas, the author
\end{abstract}

1 Doç. Dr., Necmettin Erbakan Üniversitesi, Sosyal ve Beseri Bilimler Fakültesi, Türk Dili ve Edebiyatı Bölümü (Konya, Türkiye), uengin@gmail.com, ORCID ID: oooo-0002-8249-1004 [Makale kaytt tarihi: 12.11.2019-kabul tarihi: 20.03.2020; DOI: 10.29000/rumelide.705537] 
Two theories, two practices or the extraordinary against the ordinary / E. Engin (pp. 115-123)

of Monte Cristo to Ahmet Mithat. On the other hand, Halit Ziya directs his attention to Balzac, Flaubert and The Goncourt Brothers who are the prominent names of realist and naturalist schools, and brings evidence from them to the determination about novel. He is opposed to idealism in novel and to those whose actions are directed and interpreted by idealism. He even mentions such ones with ridicule and contempt. The significant clues to the perspective of these two authors are included in their books, Ahbar-ı Asara Tamim-i Enzar and Hikâye. In this writing, above all, the clues about 'novel' and 'novelism' in the books will be dwelled on at issue. Thereafter, the novelism of the two authors will be taken a closer look based on the novels, Henüz On Yedi Yaşında and Sefile.

Keywords: Ahmet Mithat, Halit Ziya, Henüz On Yedi Yaşında, Sefile, fiction.

Ahmet Mithat ile Halit Ziya'nın roman anlayışlarındaki farklılıklar, hitap ettikleri kitle kadar romana dair üzerinde durdukları unsurlardan da çıkarsanabilir. Mithat Efendi’nin -pek çok konuda olduğu gibiroman konusunda da problematize eden, teorik bir bakışı yoktur. $\mathrm{O}$, tanımlarla ve hükümlerle uğraşır ve iş bu noktaya geldiğinde de -pek çok konuda olduğu gibi- kafası, dolayısıyla tanımları nettir/kesindir. Efendi'ye göre "roman denilen şeyin menşe-i asliyesi insan oğlunun hikâye-i havarıkı istimaya rağbet-i mecbulesi"dir (A. Mithat, 2003a: 31). Bir kere postulat(koyut) olarak bunu kabul etmesi, bu ilk adımdan sonra (neler) söyleyeceği konusunda bize epey fikir verir. Romanslar için kabul edilebilecek bu ifade, romanı icad eden Batı'daki ilk roman örnekleri için dahi ihtiyatla yaklaşılması gereken bir tespittir. Efendi, "romanların aslı"na inildiğinde rastlayabileceğimiz bu görüşü, kendi çağında da inançla/kuvvetle savunur ve alıntıladığımız bu ifade üzerinde ısrarla durur. Öyle ki Ahbar-ı Asara Tamim-i Enzar'ın daha yarısına gelmeden, "Aslın Teferruu” kısmının ilk paragrafında, dördüncü kez zikreder. Prodigeux merveilleux, roman yazarı için olmazsa olmazdır ona göre. Bunu Antik Yunan'dan E. Zola'ya kadar geçerli bir mutlak olgu olarak alır: "Müşahedât-ı adiye nevinden" gerçekleri yazacak romancıyı kimse okumayacaktır (A. Mithat, 2003a: 35).3 Romanları derece derece dörde ayırdığı bir yazısında, "en âli tabaka"dan romanlara örnek olarak Monte Kristo'yu zikretmesi bu nedenle bizi şaşırtmaz (A. Mithat, 2016: 32). Oysa H. Ziya için Monte Kristo yazarı A. Dumas'nın önemi, sadece "efkâr-ı umumiyeyi tarz-ı cedid-i hikâyeye alıştırmak"tan ibarettir (Uşaklıgil, 2012: 19).

Mithat Efendi'nin tanım ve hükümler konusunda net/kesin olduğunu belirtmiştik. Bunu, romanla ilgili bir konuda yaptığı ayrımda, tanımda açıkça görmek mümkündür: "İsmi roman mıdır? Mutlaka hayali olacak! Artık bunu tekrar hayali diye tavsif lazım gelir mi? İsmi şeker midir? Mutlaka tatlı olacak! Onu tekrar tatlı diye tavsife ihtiyaç kalır mı? Hakikiye gelince iş daha ziyade garabet peyda eder. Zira hakiki midir? O halde roman olmayıp tarih olması lazım gelecek. (...) Lakin roman mıdır? Hakiki olamaz.” (A. Mithat, 2003: 73). Efendi’nin roman anlayışına dair son olarak değineceğimiz ifadesi yine onun için tipik nitelik arz eder: "muharririn karilerine vermek istediği efkâr”(A. Mithat, 2003a: 73). Bu, aynı zamanda "hikmet" yahut "ibret" gibi kelimeleri kullanışıyla da kendini gösteren bir anlayıştır. Bu zihniyetin yansıması olarak da, baht ve talihin, roman karakterleri içinde önce "cevr ü gadr erbabı”nın tarafında olmasını ve roman ilerledikçe bu kimselerin "ceza-yı sezalarını" bulmasını ister. Böylece okuyucuya "intikam aldırmış kadar şevk ve lezzet ver”ecek olan romanda yazar bu noktaya dikkat

2 Oysa "romancı enerjisini, epik veya romans ozanlarının aksine, ilginç olaylar yaratma işine adamaz." (Antakyalığlu, 2013: 75)

3 A. Mithat'ın hakikiyunla kast ve tenkit ettiği natüralist ve/veya realist romanı anlamaktan, takdir etmekten uzak olduğu açıktır. Müşahedat' ’n mukaddimesinde bu romanın natüralist olduğunu, çünkü içindeki eşhastan birinin de kendisi olduğunu söyler. Gelgelelim bir romanı natüralist kılmada, yazarın kendini karakterler arasına koymasının uzaktan yakından en ufak bir etkisi/ilintisi yoktur. Natüralist roman için bkz.: Zola, E. (2017). Deneysel Roman, (Çeviren: Kiymet Zeyrek), İstanbul: Sel yay. Bununla birlikte, roman-toplum ilişkisini irdelerken, "romanlar her devrin inhimakatına, temayülatına göre teşekkül eder" (A. Mithat, 2003a: 70) diyerek bugünden bakıldığında kaba Marxizmi çağrıştıran -ancak yine de olguyu/gerçeği önemli bir noktadan yakalayan- dikkate değer görüşler de ortaya koyar. 
etmezse, romanın "kocakarı masalları kadar da lezzeti olamaz."(A. Mithat, 2016: 32-33) H. Ziya'nınsa bu tespite, 'esas o zaman roman kocakarı masalı derekesine iner' şeklinde karşılık vereceğini düşünmek pekâlâ mümkündür.

H. Ziya'ya göre roman, "mir’ât-ı hayat-ı beşer”, diğer bir deyişle 'olağan'a tutulan aynadır (Uşaklıgil, 2012: 12). O, "insanları tanıtmayı mütekâfil olan hikâyeler bizde masallar derecesinde bulunuyor" şeklindeki tespitiyle de, A. Mithat'ın öne çıkarmak istediği "havârık"ın, roman ve hikâyelerde (hâlâ) görünür oluşundan şikâyetçidir (Uşaklıgil, 2012: 12). Onun için roman, kesinlikle "bir vak'anın tasviri" değildir, "bir hissiyat levhası"dır (Uşaklıgil, 2012: 15). Karakterlerin eylemleriyle, psikoloji ve fizyolojileri arasında irtibat aramak/bulmaktır.

"tedkik-i hissiyat-ı beşeriye", "tedkik-i ahval-i ruh", "ahval-i ruhiye-i beşeriyeyi tedkik", "hissiyat-1 muhtelife-i ruhu tahlil", "tedkik-i hakikat"(Uşaklıgil, 2012: 13, 42, 61, 88, 126). Hikâye adlı eserinden aldığımız ve hepsi hemen hemen aynı olguya/tutuma işaret eden bu ifadeler $\mathrm{H}$. Ziya için karakteristik/tipik olarak kabul edilebilir. Başka bir pasajda, hakiki edebiyat eseri olarak kabul görecek romanlar için, "bunlar birer kitap, birer hikâye değildir; birer kalptir. Parmağımızı üzerine koyalım, darabâtını hissederiz." şeklindeki cümle de aynı şeyi söyler(Uşaklıgil, 2012: 66). Tüm bunlar iki yazar arasındaki iki temel nitelikteki farkı da gözler önüne serer: H. Ziya tedkik eden, yani arayan bir romancıdır. Roman onun için bir yolculuk-hem kişisel anlamda hem de karakterlerin kaderi anlamındatur ve destinasyon belirsizdir. ${ }^{4}$ A. Mithat ise (daha baştan) bulandır. Daha baştan, varılacak/ulaşılacak yer yahut hakikat, bellidir. İkinci farksa; ruh, hissiyat, kalp gibi kelimelerle temayüz eder. H. Ziya için son tahlilde önemli olan, iç(dünya)'tir. Gerçekten önem ve kıymet verilecek olaylar, iç dünyamızda yaşananlardır. A. Mithat ise dikkat gözünü dış(dünyay)'a odaklar. Onda duygular, isimlendirilmekle birlikte derinlemesine üzerine eğilinmeden, karakterlerin hareketlerini rasyonalize etmede kullanılan birer maniveladır. ${ }^{5}$ Roman kuramına dair en erken eserlerden birinde aksiyon romanları için yapılmış şu tespitler, Mithat Efendi'nin romanları için de geçerlidir: “Aksiyon, temel ögedir. Karakterler aksiyona bağlı ve hep bir bakıma olay örgüsüne yardım içindirler (...) Hayatın bir resminden çok, arzumuzun fantezisidirler (...) Olay örgüsü, bilgilerimizle değil, temennilerimizle uyumludur.” (Muir, 1928: 20, 23) Aynı yazarın dramatik roman için yaptığı şu tespit de H. Ziya romanları için aydınlatıcıdır: "Karakterlerin verili nitelikleri, aksiyonu determine eder ve sırası geldiğinde aksiyon, karakterleri tedricen değiştirir.” (Muir, 1928: 41)

Bu yazarın kullandığı iki ifadeyi, "dramatic tension” ve "the balance between necessity and freedom" Mithat Efendi ve H. Ziya romancllı̆̆ mukayesesi söz konusu olduğunda önemsiyor ve aydınlatıcı buluyoruz. Bu yazıda ele alınacak olan Henüz On Yedi Yaşında'da, zaruret/necessity(Kalyopi'nin, ailesinin borcu nedeniyle fuhşa mecbur oluşu) ile özgürlüğü/freedom arasındaki balans, romandaki

\footnotetext{
4 Bunu söylerken H. Ziya'nın, Natüralizm'deki determinist tavra yakınlığını unutmuş değiliz. Yalnız Natüralist romancının determinizmi dahi -karakterler söz konusu olduğunda- kendi içinde anlamlı/bütünlüklü bir deneysellik barındırır. Her ne kadar günümüzde A. Mithat'ın romancılığı yeniden değerlendiriliyor ve yeni kuramsal bakışların ışığında kıymeti gündeme getiriliyor olsa dahi söz konusu tüm analizlere karşın, Mithat Efendi’nin romanlarına dair Cenap Şahabettin’in söyledikleri hâlâ geçerli ve düsündürücüdür: "Hiçbir muharririmiz telif ederken Mithat Efendi kadar amme-i kariîni gözü önünde tutmadı. (...) İlk eserleri hangileridir bilinmez. Çünkü her eserinde ilk eser manzarası, ilk eser pürüzleri, ilk eser sathiyeti görülür. (...) Karantina dairesinden çıkıp şirket vapuruna bininceye kadar büyük bir roman tahayyül eder; vapur hareket etmeden evvel kurşun kalemiyle tesvide başlardı. İtikadımca romanlarındaki kahramanların en büyüğü kendisidir. Hikâyelerinde tahlil yok, tasvir yok, dava yahut nakz-ı dava yok, ancak bir silsile-i vekâyı vardı. (...) Dört kelime ile edâ edilebilecek bir fikir için kırk kelime hatta dört yüz kelime sarf ettiği olurdu.” (C. Şahabettin, 2013: 36, 37, 39). Bunlar aynı zamanda Mithat Efendi’nin roman sanatı söz konusu olduğunda -kurmacada savrukluğa ve laubaliliğe de kıymet atfeden postmodern bakış bir yana bırakılırsa- karşı gelinmesi çok zor, sağlam tespitler olmakla birlikte H. Ziya'nın romanlarında rastlanmayacak bulgulardır. Bu bağlamda 56 yaşındaki A. Mithat'ın Ahbar-ı Asara Tamim-i Enzar'ındaki düşünsel kolaycllığa ve Cenap'ın ifadesiyle “mutlakıyet”çiliğe, 23 yaşındaki H. Ziya’nın Hikâye'de nasıl olup da düşmediği, daha o yaşta eleştirel realizmi nasıl bu kadar iyi kavradığı da bizce izahı zor bir gerçektir.
} 
Ahmet aracılı̆̆ıyla kolayca/hızlıca yahut olağanüstü biçimde çözülecek ve romanı dramatik tansiyondan yoksun birakacaktır.

\section{İyi(lik)lerin anlatıldığı ve kazandığı bir dünya: Henüz On Yedi Yaşında}

"Romanclların teşkil eyledikleri âlem, bir âlem-i maddi olmayıp âlem-i hayâlî olduğunu düşünürseniz, romancıları muahezeye lüzum görmezsiniz.” (A. Midhat, 2000: 17) Henüz On Yedi Yaşında'nın daha başlarında geçen bu ifadeyle, hem anlatıcıyı/yazarı hem de anlatılanları muahezeden korumanın rahatlatıcı anahtarı verilir. Aynı zamanda anlatıcının/yazarın da kendi yaptığı işi, romancılığı nasıl değerlendirdiğini anlarız. Roman(okumak), asla gerçek dünyadaki tecrübelerimizle kıyas kabul edecek cinsten değildir. Burada hayâl, gerçeğin zıddı/negatifi olarak konumlandırılmıştır. Madame Bovary'nin, Ahmet Cemil'in yahut Bihter'in inkisâr ve düşüşlerindeki gibi, gerçekliklerinin ayırt edilemez bir parçası olarak değil. Romancılık da, romancıyı Tanrı'yla mukayese eden Flaubert'den bambaşka bir dünyadan seslenmektedir. Söz konusu dünyayı dolduran kavramları da Mithat Efendi, romanının pek çok sayfasına cömertçe saçar: safvet, masumiyet, ismet, iffet, merhamet, şefkat. Bunlar, muaheze edilemez bir dünyanın temel direkleridir. Bu dünyanın tahkiyesi için seçilen mekân bir genelev olsa da.. ${ }^{6}$ Saydığımız bu kavramların romanda çokça zikredilişi, (ortalama)okuyucunun duyarlığına hitâb ederek kısa yoldan etki elde etme amacını gösterdiği gibi aynı zamanda insanı -gerçek hayattakinin tersine-, küçük ve sıradan eylem ve sözlerinde arama/bulmamızın da önüne geçer.

Romanda, henüz on yedi yaşındayken fahişe olmuş Kalyopi’nin bu yaşına dek yaşadıkları da olağanüstü niteliktedir. Zengin babasının kademe kademe iflâsını görüşü, ablasının bir erkek tarafından altı yerinden bıçaklanışı, iki bacağından yoksun bir küçük kardeş, on dört-on beş yaşındayken kendisine âşı olan bir Müslüman tarafından kaçırılıp onunla nikâhlanışı, önce paravan olarak kullanılan bir terzide sonra da bir genelevde fahişeliğe başlaması.. Ancak bütün bunlardan sonra, vücudunda çıkan bir çıbanı doktorun muayene etmesine hicabından dolayı şiddetle karşı çıkması ise, belki hepsinin üstünde olağanüstü bir durumdur. Ahmet’in, çektiği nutukla Kalyopi'nin anne ve babasının zihinlerindeki "fuhuş ve mel'anet bulaşıklarını tathir" edişi (A. Midhat, 2000: 206), romanda zenginliğine dair özel bir vurgu yokken bir avukat geliriyle Kalyopi ve ailesine ev tutmada, döşemede ve nihayet Kalyopi'nin babasına iş kurmada maddi yardım yapması ve bunlara rağmen hiç para sıkıntısı çekmemesi yahut en azından romanda bundan bahis olmayışı.. Bunlar da Ahmet dolayımında, vak'adaki rasyonalite ihmâlkârlıklarından bazılarıdır. Mithat Efendi'nin Râkım'ı, işine; akşamları entelektüel mesaisini, fakirliğine rağmen para biriktirmesini ve metres tutmasını, birkaç yabancı dil öğrenişini, moda dansları kusursuz yapmasını ekleyerek nasıl olağanüstüyse, Ahmet de kişiliği ve eylemlerindeki pür iyilikle olağanüstüdür.

Roman, A. Mithat kurmacasının vazgeçilmezi iki unsurun, 'merak' ve 'ibret/hikmet’in de baskın olduğu bir yapıdadır. Parça parça dinlediği hayat hikâyesini ve sonunu öğrenmek için defalarca Kalyopi’nin müşterisi olan, onun çalıştığı yere -iğrenmesine rağmen- giden ve her defasında merakını gidermesi için

Aslında, Henüz On Yedi Yaşında'nın son cümlesinde kişilerine "sirişk-i şevk ve şadımâni” döktürecek kadar masala/melodrama yaklaşan A. Mithat'ın yazar olarak kapasite ve kabiliyetinin yeterliğinden sarf-ı nazar edildiğinde, onun bu romanda vermeyi amaçladığı fikri Müşahedat'n ön sözünde dile getirdiğini söyleyebiliriz: "ekseriya sefahat ve sefalet âlemlerinde de pek çok büyüklükler, pek çok güzellikler görüyoruz. Beșeriyeti tezyin eyleyen mealî, sefahat ve sefalet alemlerinde bile büsbütün zayi olmuyor." (A. Midhat, 2003b: 4) A. Mithat'in bu (doğru)düşüncesinin uygulamadaHenüz On Yedi Yaşında'da- ne kadar naif ve başarısız kaldığını anlamak için tamamen benzer bir sahne içeren Suç ve Ceza'daki Sonya ve Raskolnikov birlikteliğiyle ve Dostoyevski'nin ömrünün büyük kısmında beslendiği İncil'deki "İsa ve Günahkâr Kadın” meseliyle mukayese yeterlidir. Bir sayfalık bu mesel, 'tövbekâr kadın' temi düşünüldügünde çok daha etkileyici ve (insanı)kuşatıcıdır. 
Kalyopi'ye baskı yapan Ahmet, bu 'merak'ın tecessüm etmiş halidir. Elbette bu, aynı zamanda roman okuyucusunun merakını temsil ettiği ve dillendirdiği var sayılan bir figürdür.

Fuhuş âlemlerinde harcanan bir gecelik paranın fakir birisi için küçük bir servet oluşu, fuhuş yapanların ve yapılan mekânların iğrençliği, fahişelere "en güzel muamele eden Türkler" (A. Midhat, 2000: 104) gibi faydalı değinilerin yer aldığı eserde bazen de doğrudan 'irşâd'a tevessül edilir: "Akvâm-ı şarkıyyeyi akvâm-1 garbiye bozmuştur (...) Ey Frenkler! Türkiye'de esareti men edeceğiz diye birtakım medeniyetperverâne ve hürriyetperestâne sözlerde bulunursunuz! Halbuki bizde hiçbir esir böyle kerhânelerde erâzil-i avâma ferşpâ olmak için satılmaz.” (A. Midhat, 2000: 123, 105)

Tüm yukarıda söylenenlerden hareketle romana dair bir hususu daha belirtmek gerekir. Bu da, 'gerçekçilik'tir. Bununla gerçekçi(realist) romanın poetikasını değil, roman sanatının temel direklerinden birini kast ediyoruz. Henüz On Yedi Yaşında için Tamer Kütükçü’nün gerçekçilik bağlamında yaptığı şu tespitlerin hiçbirine katılmak mümkün değildir:

\begin{abstract}
"Henüz On Yedi Yaşında romanında yazar stratejisi, öyle görünüyor ki, bu evlerin sosyal işlevi ya da toplumdaki tarihsel karşılığından ziyade, buradaki yaşamı -tüm gerçekliği ve tüm çıplaklığıyla- gözler önüne sermektir (...) 'Gözlem’in böyle uzunca randevu evi üzerinde teşekkülü, kuşkusuz, buradaki yaşamı duyarlılıkla incelemeye endeksli bir yazar tutumuna elverir (...) Yazarın bu aşamada söylem otoritesini fahişelerden yana kaydırması, söz konusu kitle ve de ilgili olguya 'toplumsal ahlak' nazarından yaklaşmayacağını, bilakis bu kitle ya da olgunun sorunlarına eğileceğini ima eden bir anlatıcı tavrını daha bu noktada görünür kılmaktadır (...) Nitekim romanın sonraki sayfalarında, bakış açısı, yine uzunca sayılabilecek bir süre, randevu evinin mekânsal ayrıntıları üzerinde dolaşır. Bu tasvirsel ögeler arasında, evin lambası özellikle ön plandadır. Diğer tüm komșu evlerde ışıklar söndüğü halde, bu evde ışığın hâlâ yanıyor oluşu bile, Ahmet'e, sanki buraya gelenlere tüm rezaleti göstermek ve utanmalarını onlara telkin etmek için yanar gibi gelir.” (Kütükçü, 2018: 242, 247, 243244)
\end{abstract}

Romanı okumamışlar için yanıltıcı -"söz konusu kitle ve de ilgili olguya 'toplumsal ahlak' nazarından yaklaşmayacağı”- ve beklentileri fazlasıyla yükseltecek -“tüm gerçekliği ve tüm çıplaklığıyla”- bu hükümler, okuyucuyu ancak bir Zola -mesela Nana-, Maupassant yahut Goncourt Kardeşler romanına hazırlamada uygun olabilir. Bilakis, Mithat Efendi bu romanda tam da "söz konusu kitle ve de ilgili olguya 'toplumsal ahlak' nazarından yaklaş”ır. Temeli, binası budur ve Kalyopi’nin 'acıklı' hikâyesi de okuyucu için burada bir çeşit, binanın cephelerindeki boyadır. Bununla birlikte roman tümden, bir ahlak hocasının diskurundaki edâyı/tonu taşımadı̆̆ı gibi yer yer gerçekçi alev çakımları da barındırır; Kalyopi’nin mesleği dolayısıyla vücudunda oluşan morluk ve çürüklere işaret edilmesi gibi. Ancak gerçek hayatta lambalar bizi sadece ışılarıyla aydınlatırlar; "buraya gelenlere tüm rezaleti göstermek ve utanmalarını onlara telkin etmek için yanar gibi gel”işleriyle değil.7 Dahası, A. Mithat, Henüz On Yedi Yaşında'ya mekân olarak seçtiği yeri/âlemi bilmez değildir. Oğlunun yazdığı kitapta ve kendi eseri Menfầ da bu gerçeğe dair birçok açı ve örtük ipucu vardır. Ancak iş yazmaya gelince, büyük sosyolog Şerif Mardin’in ünlü bir tebliğinde dile getirdiği teze hak verircesine, 'kötülüğün/şeytaniliğin bastırılışına' tanık oluruz. Oysa Faulkner'ın da dediği gibi: "Bir yazarın sahip olması gereken özelliklerden biri de şeytandır. Şeytanları tarafından yönlendirilmesi gerekir.” (Inge-Yoviç, 2014: 209)

\title{
Tutkularının tükettiği bireyler
}

Her ne kadar romanda mebzûl miktarda; "zavallı kız", "zavallı kızcağız”, "bedbaht kız", "masum çocuk" gibi ifadeler geçse, yer yer anlatıcının duygusallaştı̆̆ını(ve bizi duygulandırmayı amaçladığını) fark etsek

Nesneler de gerçek(çi)lik etkisi yaratma için kullanılabilir ve bu durumda hem mekâna hem de orada yaşayana dair ipucu verirler. R. Barthes'in böyle bir analizi için bkz.: Watt, I.- Barthes, Roland. (2006). Gerçekçilik ve Romansal Biçim'in içinde, (çeviren: Mehmet Sert), 2. bs., İstanbul: Yirmi Dört yay. 
ve yazarının acemilik eseri de olsa, Sefile'nin Henüz On Yedi Yaşında'ya kıyasla, sanatsal nitelik ve gerçekçilik açısından açık ara önde olduğunu belirtmek gerekir. Kalyopi'den birkaç yaş daha küçük olan Sefile'deki Mazlume, esasen yine A. Mithat retoriğine yakın bir şekilde tasvir edilir: "Mazlume paçavralar altında ulvî bir kalp taşırdı.” (Uşaklıgil, 2016: 22) Burada anlatıcı -A. Mithat gibi-, karakterin içinde bulunduğu durumu yansıtmakla birlikte ayrıca harcıalem sıfatlara, tamlamalara -dolayısıyla ifade fazlalıklarına- başvurur: "Biçare, duzehi azaplar (...) suzişli vaka (...) Ne ıstıraplı gece! Ne hazin bir hal! (...) Ne acı vukuf, ne müthiş ittılâ!” (Uşaklıgil, 2016: 23, 24, 26, 30)

Mazlume, natüralist romancıların dikkatle üzerinde durduğu 'soya çekim'e örnektir: "Filhakika Mazlume validesinin hastalıklarından hisse-yâb olmuştu." (Uşaklıgil, 2016: 29) Bahsi geçen hastalık, ihtinak-ı rahm, yani hysteria'dır. Bugün tıpta terk edilmiş olsa da bir asır öncesine kadar kadınlardaki sinirsel bozuklukları teşhis için kullanılan ve semptomları arasında aşırı cinsel isteğin de görüldüğüne inanılan -hysteria, 'uterus'tan gelir- bu hastalığın Mazlume'nin düşüşünde etkili olduğunu yahut anlatıcı tarafindan böyle bir imâda bulunulduğunu söylemek mümkündür. Ortalama ahlaki ölçütlere sahip ve bunlara da kuvvetle tutunan Mazlume'nin düşüşünde, aklına/ruhuna rağmen bedeninin(isteklerinin) baskın çıkmasıdır belirleyici olan. Kuşkusuz burada yine natüralizmde önemli bir dikkat noktası olan çevre/muhit de, Mihriban ve kızı İkbal'in fuhuşla geçimlerini sağlayan kişiler olması vesilesiyle hatırlanabilir. Buna, Mazlume’ye romanın hem başında hem de sonunda, sokağa düşmüşken, paçavralar içinde insanların gözü önündeyken, kimse tarafından yardım eli uzatılmamasını da eklemek gerekir. Aynı hususta İkbal de bir örnektir. O da çocukluktan çıkmaya başladığı dönemde, dul kalmış annesinin birçok erkekle ilişkisine tanıklık eder ve sonunda onun vardığı nokta da fuhuş batağı olur. İkbal bu tanıklıkların üzerindeki etkisini şöyle ifade eder: "Gerçi saffetime halel gelmemişti, lakin validemin tarz1 hayatına alışır gibi olmuştum.” (Uşaklıgil, 2016: 45) Bunlardan hareketle yeri gelmişken belirtmek gerekir ki Sefile'deki istisnasız tüm karakterler 'kötü', insan olmanın kusurlarını gösteren nitelikteyken, Henüz On Yedi Yaşında'daki çoğu isim 'iyi’ ve dahası, kötü olanlar dahi iyi düşünceleri dillendiren, ‘tövbe eden’ niteliktedir. Buna rağmen Henüz On Yedi Yaşında'dakilerin kötülükleri tasvirîdir/sathîdir, analitik değildir ve sadece diskurda kalır. Bu nedenle okuyucuyu etkilemez. Sefile'dekiler ise, hırsları, arzuları ve kendilerini şehvete bırakışlarıyla okuyucunun velev ki nefretini çekerek dahi olsa, onu etkilerler. Diğer bir deyişle, kötülükleri samimidir, içlerinden gelir ve bu 'iç', romanda anlatıcı tarafından belli bir düzeyde dahi olsa analiz edilir.

Hem İkbal hem de Mazlume, ahlaken düşmeden önce, ekonomik olarak düşerler. Zaten bir bakıma ikincisi, ilkinin hazırlayıcısıdır. Kendisinin fakirliğe düşmesinden sonra tanıştığı İkbal'in benzer hikâyesini ve fuhuşa yuvarlanışını dinleyen Mazlume, artık İkbal'e âdi bir fahişe nazarıyla bak(a)maz. "Mahkeme-i vicdanında genç kadını mazur görmeye başla"r ki bu aslında romandaki düşmüş karakterlere -ki hepsi öyledir- anlatıının yaklaşımıyla da aynıdır (Uşaklıgil, 2016: 47). Bu bakımdan, hem A. Mithat'ın hem de H. Ziya'nın roman kişilerini yargılamaktan uzak durduğu belirtilebilir. Ancak burada yine de bir fark düşünülebilir; ilki bunu hayat karşısında 'babacan' tavrı, ikincisi ise trajik duyarlığa sahip oluşu yahut realist/natüralist poetikaya olan bağllığı nedeniyle göstermiş olabilir.

Yukarıda belirtildiği gibi, Sefile'deki karakterler, esasen tutkularının yakıp tükettiği kişilerdir. Örneğin İkbal, kendisi için "mecnunane bir aşka muhtaç olan ve mahrumu olduğu lezaiz-i ruhaniyeye tamamen müstait bulunan kalbim" ifadesini kullanır ve ekler: "Ben fecî muaşakalar, şairane muhabbetler tasavvur ederdim.” (Uşaklıgil, 2016: 51) Anlatıcı da onun için: "Bilakis bu kadında hissiyat-ı şehvaniyeye lezaiz-i hayata şiddetli bir arzu, meftunane bir inhimak vardı.” der. (Uşaklıgil, 2016: 51) 
Böyle eğilimleri bulunan İkbal, daha genç kızken kendisinden 20-25 yaş büyük birisiyle evlendirilir ve bundan sonra kendi kendine bir karar/söz verir: "Kalbimde garip bir arzu-yı intikam hâsıl olmuştu. Benim için bir azab-ı elîm olmaktan başka bir şeye yaramayan hayattan onu telvis ederek ahz-ı intikam etmeye karar verdim. Zelilâne yaşamak, sefilâne ömür sürmek istiyordum.” (Uşaklıgil, 2016: 52) Kendisini fuhuşa bıraktıktan sonraki günlerini ise şöyle anar: "Hissiyat-ı ulviyede bulamadığım lezzeti, hayat-ı şehvaniyeden almaya başlamıştım.” (Uşaklıgil, 2016: 52) Daha yazarlı̆̆ının ve yirmili yaşlarının başındaki H. Ziya'da gerçek bir romancı cevheri bulunduğunun bir kanıtı da bizce bu satırlardadır. İnsan ruhunun hiç ışık görmemiş taraflarından birine bir kibrit alevi kadar da olsa bu satırlarda ışık tutulduğunu görürüz. Maalesef kaderine meydan okuyan, onun üstüne üstüne giden İkbal'in bu yönü romanda derinleştirilmemiştir/geliştirilmemiştir.

İkbal'in kaderine karşı atılımı yine de bizleri yanıltmamalıdır; zira o tam da Fikret’in şiirlerinde -Süha ve Pervin, İnanmak İhtiyacı vb.- ve usta H. Ziya'nın eserlerinde göreceğimiz psikolojik karakter ve duyarlığın prototipidir: hayatı gördükten, anladıktan sonra ona karşı mağlubiyeti baştan kabullenip çabalamanın yararsızlı̆̆ına kanaat getirmek. Bu, daima eylem yerine düşünmeye ve düşüncesi kendine yönelmeye eğilimli bir mizaçtır. Sonuçta aşırı incelik ve bununla birlikte toplumsal normların karşısında 'cansızlık' olarak nitelenecek duruma varılır: "Aşırı incelik(raffinement), yetersiz canlılığın göstergesidir; sanatta, aşkta ve her şeyde.” (Cioran, 2019: 96) İkbal ise kendi durumunu Mazlume’ye doğrudan ifade eder: "Ben bundan sonra hayatımı tebdil edecek kadar hayatla uğraşamam (...) Ben düşünmekten yoruluyorum, değil ki çalışmak...” (Uşaklıgil, 2016: 56)

İkbal'in içsel yolculuğu, kendisini yavaş yavaş tüketen bir süreçtir. Tutku/şehvet ve/ya aşk, sonunda onu gerçek anlamda ölüme kadar götürür. İlginç bir biçimde, bu daimonik yolculuğun ${ }^{8}$ sonucunu onun yüzüne karşı saf Mazlume önceden haber verecektir: "Mazlume cesurane ilerleyerek dedi ki: - Ben hepsini biliyorum! İkbal şiddetle başını kaldırdı: - Neyi biliyorsun? - Bu muaşakanın seni öldürdüğünü, hayatının... Mazlume sözünün buradan aşağısını pek yavaş bir sesle ve kızararak devam etti: - Hayatının şehvete feda olduğunu biliyorum. İkbal bağırarak dedi ki: Lâkin ben onu seviyorum!..” (Uşaklıgil, 2016: 71) Cinsellik ve aşkın Janus'ün iki yüzü gibi olup olmadığı/ayrıştırılabileceği meselesi bir tarafa, belirtildiği gibi burada dikkat çekici olan İkbal'in sonunu Mazlume'nin haber verişidir. Ciddi hastalığı dolayısıyla tebdil-i mekân/hava ettikleri yerde İkbal'in sağlığı biraz düzelir gibi olurken, İhsan'la İkbal arasında "evvelki kadar şedit” olmasa da yeniden başlayan muaşaka, bu kez İkbal'i tekrar iyileşemeyecek şekilde yatağa düşürür ve ölümüne neden olur. İhsan'ın durumu da benzerdir. İntikam arzusu duyduğu İkbal'e aynı zamanda taparcasına âşıktır. İlk buluşmalarında iğrenme duygusuyla ayrıldığı "bu fahişeyi seviyordu”r (Uşaklıgil, 2016: 81). Anlatıcının hem İkbal hem de İhsan’ın duygularından, içinde bulunduğu durumdan bahsederken birkaç kez "şedit" sıfatını kullanması boşuna değildir. Bu iki isim, söz geçiremedikleri şiddetli duyguları, arzuları nedeniyle zelil/sefil bir hayat sürmeye, kendilerini sevenleri görmezden gelmeye başlarlar. Nihayet tutkuları, birbirlerini de yok edecek noktaya gelir: İkbal, ağır hastayken, şiddetli aşk hayatına devam etmeyi göze alarak; İhsan ise, hastalı̆̆ın fiziksel olarak değiştirdiği İkbal'den soğuyup Mazlume'ye ilân-ı aşk ederek. Roman ilerledikçe, "aşkın kuvve-i kahharanesi”nin pençesine Mazlume de düşer (Uşaklıgil, 2016: 113). O da İhsan’a şiddetli bir aşkla bağlanır. Bu pençelerde, anlatıcının ifadesiyle "dereke-i hayvaniyete süratle sukuta" (Uşaklıgil, 2016:

Roman kahramanı için kullanılan "içsellik", "içsel yolculuk" ve "daimonik" ifadeleri için bkz: (Lukacs, 2003: 90-98). İkbal, yine Lukacs'ın ifadeleriyle: "ideal ile idea arasında, psike ile ruh arasında bir mesafe olduğunu unut” an türde, soyut idealist bir karakterdir. O, "ruhun zaten var olan bir fikre daimonik takıntısından kaynaklan"an "ruh küçülmesi”nin örneğidir. Onun dillendirdiği "fecî muaşakalar, şairane muhabbetler", zikredilen "daimonik takıntının" ve aynı zamanda iç dünya/öznellikle dış dünyanın uyumsuzluğunun göstergesidir (Lukacs, 2003: 101, 102). Sonunda "ruhların daralması"/küçülmesi, "saf bir daimonizm üret”ir (Lukacs, 2003: 110). Yani İkbal, kendi iç potansiyeline denk düşmeyen yazgısından intikam için, bile isteye fuhuş batağına düşer. 
84) başlayan İkbal ve İhsan'ın yanında Mazlume, romanın sonunda gerçek anlamda bir hayvan gibi, İhsan'ın boğazına yapışacak ve dişleriyle damarlarını kopararak, bir zamanlar tutulduğu adamı öldürecektir. Bu noktaya gelmeden biraz öncesindeyse, İhsan tarafından yüzüne "fahişe" olduğu haykırılan Mazlume'nin -tıpkı İkbal gibi-, istediği hayatı yaşayamayınca, hayattan intikam almak için gerçekten fahişe oluşu vardır. ${ }^{9}$ Mazlume'nin çalıştı̆̆ 1 yerdeki fahişeler; onunla her seferinde alay edişleri, iğneli sözleri, kısaca 'kötülük'leriyle; Henüz On Yedi Yaşında'da görülen aynı türden kadınlara kıyasla daha gerçektir/inandırıııdır.

Romandaki üç ana karakter -Mazlume, İkbal, İhsan- söz konusu olduğunda da okuyucu için onlara hem nefret hem de merhamet duymaya imkân verecek unsurlarla karşılaşlır. Hiçbirisi hayattan istediğini alamamıştır; ya da kendilerine biçilen hayatlara kanaat etmemişlerdir. İkbal de İhsan da annelerinin onlara uygun gördüğü, hazırladığı hayatı yaşamak istemezler. Bunun bedelini de öderler. Mazlume'ye gelince, romanın sonunda en düşkününden bir fahişe olarak gördüğümüz bu karakter için anlatıcının söyledikleri, hayatının, natüralist bir hâkim tarafından verilen/okunan hükmü gibidir: "Lakin Mazlume için bu netice tabii görünüyordu. Başka bir hayat görmemiş olan bu bedbaht kız, kendisi için bu hayatı zaruri buluyordu." (Uşaklıgil, 2016: 155) Ancak bu sözler, Mazlume'nin kaderine razı olduğunu da düşündürmemelidir. O da İkbal ve İhsan gibi, "hayata karşı şiddetli bir adavet duy"ar ve ilk ikisi gibi, "hukukunun gasp olunduğuna hükme"der (Uşaklıgil, 2016: 171). Kendisine, "niçin herkesten ziyade bedbaht, herkesten ziyade felaket-dide” olduğunu sorar (Uşaklıgil, 2016: 172).

\section{Sonuç}

H. Ziya'nın romanındaki üç temel karakter de W. Faulkner'ın Nobel konuşmasında dile getirdiği "kendisiyle çelişen insan yüreği/human heart in conflict with itself"- insanlık durumunun göstergelerindendir/kanıtlarındandır. Tıpkı H. Ziya'nın büyük romanlarındaki Bihter, Ömer Behiç gibi. Zaten yazarın Hikâye'de roman üzerine konuşurken sık sık insan kalbine ve kalpteki duygulara atıf yapması bu bağlamda değerlendirilmelidir. Faulkner nasıl ki bir yazarın ancak alıntıladığımız gerçeği anlatırken çektiği acıyı ve döktüğü teri anlamlı bulduysa, H. Ziya için de roman yazmanın anlamı budur. Natüralizmden beslense de romanlarını ve karakterlerini, bir teorinin ispatı için kullanılacak birer araç olarak görmez. Karakterler, kendilerini aşan, dışsal faktörlerle -fakirlik, ebeveynler..- çatışırlar ve neticede kalıcı hasarlar alırlar. Toplum onları affetmez. Sefile'deki fuhuş gerçeğinde/olgusunda iğrençliğine vurgu yapılmanın yanı sıra-, daima tensel haz/arzu da rol oynar. Diğer bir deyişle, özneyle kökensel bir bağı da vardır. Oysa enteresan bir biçimde, edebiyata bilimsel bir hüviyet kazandırma iddiasındaki natüralizmden hiç hoşlanmayan A. Mithat'a göre -Henüz On Yedi Yaşında'da- fuhuş, topluma sirayet etmiş bir hastalıktır. Dışsal etmenlerle gelmiştir, tedavisi mümkündür.

A. Mithat'ın Henüz On Yedi Yaşında'sında gördüğümüz kişilerin -örneğin Kalyopi ve ebeveynleribaşlarından geçen kötü ve acı olaylar, absorbe edilir sanki kişiliklerinde ve kalıcı hasar bırakmaz. Hepsi, bu kötü olaylar sona erdikten sonra, hayatlarına kaldıkları yerden devam ederler. Bir bakıma denilebilir

\footnotetext{
$9 \quad$ "Madem ki kendisine fahişe deniliyordu, o da fahişe olacaktı.” (Uşaklıgil, 2016: 154) Mazlume'nin fahişeliğe bilerek düşüşü, "Goethe'nin Faust'undaki gibi kederi ve mutluluğu sonuna kadar deneyimleme arzusunu dişa vuran bir bireyin yaptığı tercihi ortaya koy"maz kesinlikle, bununla (ve Faust'la) Mazlume arasında hiçbir benzerlik yoktur (Arvas, 2019: 29). Mazlume, B. D’Aurevilly’nin güzel hikâyesi “Bir Kadının İntikamı”ndaki Sierra Leone Düssesi'ne benzer. Sadece politik gayelerle evlendirildiği kocasını sevmeyen ama saygı duyan Düşes, evlendikten sonra büyük bir aşkla bir başkasını sever. Aşkı da karşılıksız değildir. Ama yine de kocasını aldatmaz. Zamanla durumu anlayan koca, karısının sevdiği adamı öldürür. Bunun üzerine Düsses, kaçarak ülkesini terk eder ve soylu kocasından, Dük'ten intikam almak için Paris’te fahişe olur. Kendi hikâyesini de müşterilerine anlatarak, kocasının ismini lekelemiş ve intikamını almış olur (D’Aurevilly, 2014: 279-322).
} 
ki, hayatta kötülük vardır ama bu a'razdır. Asıl olan iyi(lik)lerdir. Bu nedenle insan için daima 'yeniden başlamak’ mümkündür. Toplum da anlatıcı da (ve Tanrı da) affedicidir.

\section{Kaynakça}

Ahmet Midhat Efendi. (2000). Henüz On Yedi Yaşında, (Hazırlayan: N. Sağlam), Ankara: TDK Ahmet Midhat Efendi. (2003b). Müşahedat, (Hazırlayan: Osman Gündüz), 2. bs., Ankara: Akçă̆. Ahmet Mithat. (2003a). Ahbar-1 Asara Tamim-i Enzar, (Hazırlayan: Nüket Esen), İstanbul: İletişim.

Ahmet Mithat Efendi. (2016). Edebiyat Yazıları 1, (Hazırlayan: H. H. Durgun- F. Gökçek), İstanbul: Dergâh.

Antakyalığlu, Z. (2013). Roman Kuramına Giriş. İstanbul: Ayrıntı.

Arvas, D. (2019). “Gönüllü Kurbanlı̆̆ı̆ Cisim Hali: Sefile” Siyah Endişe’nin içinde, (Hazırlayanlar: D. A. Küçük- M. Narcı), İstanbul: İletişim yay., s. 23-34.

Cioran, E. M. (2019). Yeni Tanrllar, (çeviren: Murat Erşen), İstanbul: Redingot.

Çok Değil, Güzel Yazan Yaşar! Cenap Şahabeddin'den sanat ve edebiyat üzerine yayınlanmamış yazılar (2013). (Hazırlayanlar: H. Tuncer- E. Genç), İstanbul: Babıali Kültür.

D’Aurevilly, B. (2014), Şeytani Öyküler, (çeviren: Aysel Bora), 2. bs., İstanbul: Can.

Kütükçü, T. (2018). Hayatın Dinamiklerinden Yazınsal Metne Tanzimat Romanı, İstanbul: Ötüken.

Lukacs, G. (2003). Roman Kuramı, (çeviren: Cem Soydemir), İstanbul: Metis.

Muir, E. (1928). The Structure of the Novel, London: Hogarth Press.

William Faulkner'la Konuşmalar. (2014). (Derleyen: M. T. Inge, Çev: A. K. Yoviç), İstanbul: Agora yay. Uşaklıgil, H. Z. (2012). Hikâye, (Hazırlayan: Fazıl Gökçek), İstanbul: Özgür.

Uşaklıgil, H. Z. (2016). Sefile, (Hazırlayan: Ö. Faruk Huyugüzel), 2. bs., İstanbul: Özgür. 